\title{
Relationships between Updraft Characteristics and Cloud-to-Ground Lightning Activity in Warm-Season Convective Storms in the Kanto Region, Japan
}

\author{
Namiko Sakurai, Shingo Shimizu, Yukari Shusse, Shin-ichi Suzuki, \\ Takeshi Maesaka, Kaori Kieda, and Koyuru Iwanami \\ National Research Institute for Earth Science and Disaster Prevention, Tsukuba, Japan
}

\begin{abstract}
This study investigated two aspects of the relationship between cloud-to-ground (CG) lightning activity and lightning indices (LIs) based on updraft strength recorded in the Kanto region of Japan: (1) the relationship between CG lightning frequency and LIs based on updraft strength, and (2) the relationship between the occurrence of CG lightning and LIs based on updraft strength. Data from two $\mathrm{X}$-band polarimetric radars recording at a high temporal resolution (every $1-2 \mathrm{~min}$ ) were used to investigate updraft evolution associated with CG lightning activity. The LIs of updraft volumes were found to be well correlated with CG lightning frequency for threshold values of updraft speeds of $>5$ and $>10 \mathrm{~m} \mathrm{~s}^{-1}$ (correlation coefficient $(r)>0.7)$; this result supports the findings of a previous study in the North America. The LIs derived from updraft strength studied here, updraft volumes at vertical velocities of $>0$, $>5$, and $>10 \mathrm{~m} \mathrm{~s}^{-1}$ and maximum updraft speed, were also well correlated with the occurrence of CG lightning (the highest hit rate (HR) was $>0.7$ when probability of detection (POD) was $>0.9$ ). The results demonstrate the potential for updraft parameters to be used as more accurate LIs than those based on reflectivity parameters.

(Citation: Sakurai, N., S. Shimizu, Y. Shusse, S. Suzuki, T. Maesaka, K. Kieda, and K. Iwanami, 2015: Relationships between updraft characteristics and cloud-to-ground lightning activity in warm-season convective storms in the Kanto region, Japan. SOLA, 11, 177-180, doi:10.2151/sola.2015-039.)
\end{abstract}

\section{Introduction}

Lightning, a high-impact phenomenon associated with welldeveloped cumulonimbus clouds, causes significant property damage and economic losses. Hence, the ability to more accurately predict and provide warnings regarding the timing and location of lightning acuity would be of immense social and economic value.

Several types of radar-based indices are currently used to estimate and predict lightning activity. Updrafts are important electrical generators because they drive the development of graupel and ice crystals, and increase the frequency of particle collisions within updraft regions. Such mixture of ice crystals, graupel, and supercooled cloud droplets is thought to produce electrification by the noninductive graupel-ice mechanism. Therefore, updraft parameters should be useful lightning indices. Zipser and Lutz (1994) suggested that updraft speeds exceeding certain threshold values are necessary for rapid electrification. They determined that the magnitude of these thresholds was $6-7 \mathrm{~m} \mathrm{~s}^{-1}$ for the mean updraft speed and $10-12 \mathrm{~m} \mathrm{~s}^{-1}$ for the peak updraft speed in the layer between 0 and $-20^{\circ} \mathrm{C}$. Wiens et al. (2005) reported that the total flash rate was well correlated with the updraft volumes at vertical velocities (herein denoted w) of $>10 \mathrm{~m} \mathrm{~s}^{-1}$ in a tornadic supercell. Deierling and Petersen (2008) investigated the relationships between total flash rate and various updraft indices (updraft volume, maximum updraft speed, and mean updraft speed) for the

Corresponding author: Namiko Sakurai, National Research Institute for Earth Science and Disaster Prevention, 3-1 Tennodai, Tsukuba 305-0006, Japan. E-mail: sakurain@bosai.go.jp. (C)2015, the Meteorological Society of Japan. combined data of 11 distinct thunderstorms in the Colorado/Kansas High Plains and Northern Alabama. They reported that correlation coefficients between updraft volume in the charging zone (above the $-5^{\circ} \mathrm{C}$ level) and the total flash rate were especially high for lightning indices (LIs) based on updraft volumes of $>5$ and $>$ $10 \mathrm{~m} \mathrm{~s}^{-1}$. Their conclusions were based on the analysis of updraft evolution over intervals of 3-8 $\mathrm{min}$. To refine the use of lightning indices related to updraft evolution, sophisticated radar scan strategies that incorporate both a high temporal resolution $(\sim 2 \mathrm{~min})$ and detailed coverage of the 3D structure of the convection will be required, as vigorous convective clouds can change significantly over just a few minutes (Battan 1975). In addition, high temporal resolution (acquisition of plenty of samples) is important to obtain significant correlation coefficients. Therefore, a necessary prerequisite to any such refinements will be the analysis of case studies involving multi-Doppler radar analysis based on such sophisticated scan strategies.

The National Research Institute for Earth Science and Disaster Prevention (NIED) of Japan conducted intensive high-temporalresolution lifecycle observations of summertime cumulonimbi, over the period 2011-2014, using two X-band polarimetric radars in the Kanto region (Fig. 1). During these intensive observations, a volume scan was obtained every 1 or $2 \mathrm{~min}$, which is a higher temporal resolution than used in the previous studies referred to above. The objective of this study was to investigate stormscale relationships between cloud-to-ground (CG) lightning and thunderstorm kinematic characteristics in the warm season in the Kanto region of Japan.

\section{Observations and data}

We used observations from two X-band polarimetric radars located at Ebina City (EBN radar) and Kisarazu City (KSR radar; Fig. 1), 2D CG flash data provided by the Japanese Lightning Detection Network (JLDN), and radiosonde soundings obtained from Tateno, Japan to investigate the relationship between CG lightning and the kinematic characteristics of thunderstorms. The X-band radars were operated at a pulse width of $0.5 \mu \mathrm{s}$ and

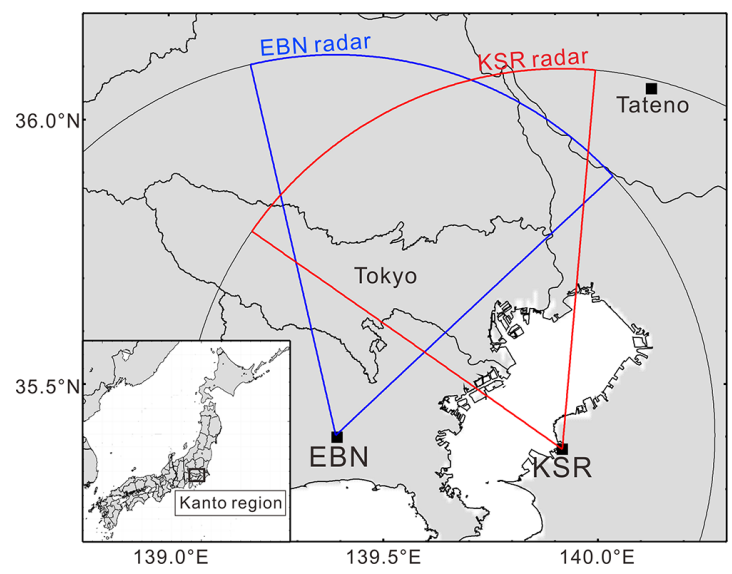

Fig. 1. Locations and observation ranges of X-band polarimetric radars installed at Ebina City (EBN) and Kisarazu City (KSR). 
an observational range of $80 \mathrm{~km}$ (Fig. 1). The beam width of the EBN radar was $1.3^{\circ}$ and that of the KSR radar was $1.0^{\circ}$. During the intensive cumulonimbus lifecycle observations, the EBN and KSR radars performed sector scans at an azimuthal width of $60^{\circ}$ (Fig. 1). Two types of scan strategies were used: the first employed 8 elevation angles in the range $0.7^{\circ}$ to $11.5^{\circ}$, whereas the second employed 17 elevation angles in the range $0.7^{\circ}$ to $19.8^{\circ}$. The temporal resolution of the former (latter) sector volume scans was 1 (2) min. The radars scanned four thunderstorms during the intensive observation period in 2012 and 2013; on 2 September 2012, and 21 and 22 August 2013 the scanning interval was $2 \mathrm{~min}$, and on 2 September 2013 the scanning interval was $1 \mathrm{~min}$.

The horizontal reflectivity $\left(\mathrm{Z}_{\mathrm{H}}\right)$ data obtained from the EBN radar and the Doppler velocity $\left(\mathrm{V}_{\mathrm{D}}\right)$ measured by the EBN and KSR radars were used for the analysis. The $Z_{\mathrm{H}}$ data from the EBN radar were corrected for rainfall attenuation using the relationship between the specific attenuation and the specific differential phase $\left(\mathrm{K}_{\mathrm{DP}}\right)$ derived from the $\Phi_{\mathrm{DP}}$ data (Kim et al. 2008; Maesaka et al. 2011). These variables were interpolated onto a Cartesian grid system (Cressman 1959). The spatial resolution was $1 \mathrm{~km}$ in the horizontal and $500 \mathrm{~m}$ in the vertical. The dual Doppler radar analysis was performed by referring to a combination of upward and downward integration schemes (Ray et al. 1980), based on the method proposed by Protat and Zawadzki (1999). It should be noted that the results from the upward integration scheme were used for heights below $2 \mathrm{~km}$, while the results from the downward integration scheme were used for heights above $2 \mathrm{~km}$. The $2-\mathrm{km}$ height was selected because the upward integration scheme accumulates errors up to the top of the domain, and the accuracy decreases considerably above $2 \mathrm{~km}$ (Doviak et al. 1976). On the other hand, the downward integration scheme can yield a more accurate estimation of vertical velocity (Doviak et al. 1976), and the accuracy should be reliable above the melting layer. Therefore, the results of the downward integration scheme were used in the upper layer in our analysis.

The following procedures were used to ensure the accurate extraction of the 3D radar data from the targeted cumulonimbus clouds, which was necessary for the calculation of updraft volume, maximum updraft speed, and mean updraft speed. The analysis period was determined as follows: the start and end times were defined as the times at which the area within a closed horizontal contour of some threshold $Z_{\mathrm{H}}$ value at a height of $3 \mathrm{~km}$ was $>10$ $\mathrm{km}^{2}$ for the first time and last time, respectively. The area of the targeted cumulonimbus cloud was vertically expanded from the surface to $20 \mathrm{~km}$ to extract the $3 \mathrm{D}$ form of the targeted cumulonimbus. To account for the tilt of the cumulonimbus, the horizontal area of the targeted cumulonimbus was extended by $4 \mathrm{~km}$ in all directions. A threshold value of $\mathrm{Z}_{\mathrm{H}}\left(\mathrm{Z}_{\mathrm{H}_{\mathrm{T}} \mathrm{T}}\right)$ of $35 \mathrm{dBZ}$ was used to discriminate between the area of the targeted cumulonimbus and that of the surrounding clouds, except for the thunderstorm on 2 September 2013, for which we used a $Z_{H_{\mathrm{T}}}$ value of $36 \mathrm{dBZ}$, which was the minimum value possible to discriminate between the targeted cumulonimbus area and the area of surrounding clouds. The area of the targeted cumulonimbus at a height of $3 \mathrm{~km}$ at each time increment was tracked automatically using the Algorithm for the Identification and Tracking Convective Cells (AITCC; Shimizu and Uyeda 2012). Note that the data from periods when the whole of the targeted cumulonimbus was not observed by the two radars (as it moved in or out of the observation domain) were excluded from the analysis.

The CG lightning data used in the study were provided by the JLDN and were derived (as of 2011) from ten IMPACT-ESP, nine LPATS-IV, and eleven LS7001 sensors (Saito et al. 2014). The CG lightning data consisted of CG lightning flashes, the date and time of occurrence, the location (longitude and latitude), and the electric current; the detection efficiency was $90 \%$ or better, and the location accuracy was within $500 \mathrm{~m}$ (http://www.franklinjapan.jp/ contents/observation/).

Upper air data were obtained from the Tateno Aerological Observatory of the Japan Meteorological Agency (JMA). The sounding data were interpolated every $5 \mathrm{hPa}$ in the vertical dimension to find the altitude corresponding to a given temperature.

\section{Results}

\subsection{Overview of the four thunderstorms}

We analyzed data from four thunderstorms observed during the summer seasons of 2012 and 2013 by the EBN and KSR radars (Supplement 1). The first was a multicell thunderstorm (T1) observed on 2 September 2012 (Figs. 2a, b, c). The analysis period consisted of part of T1's lifetime. The maximum echo-top height was approximately $10 \mathrm{~km}$, which was the lowest maximum echo-top height among the four thunderstorms (Fig. 2a). The CG lightning occurred when a strong maximum updraft speed $\left(\mathrm{w}>10 \mathrm{~m} \mathrm{~s}^{-1}\right.$ ) was maintained after the maximum updraft speed became especially strong ( $\mathrm{w}>15 \mathrm{~m} \mathrm{~s}^{-1}$ ) above an altitude of $-5^{\circ} \mathrm{C}$ (Figs. $2 \mathrm{~b}, \mathrm{c}$ ). The second case was an isolated thunderstorm (T2) observed on 21 August 2013 (Figs. 2d, e, f). We obtained $3 \mathrm{D}$ data from T2 for nearly its entire lifetime from both the EBN and KSR radars. The maximum updraft speed above an altitude of $-5^{\circ} \mathrm{C}$ was the weakest among the four thunderstorms (Fig. 2e). The CG lightning occurred when, or after, the echo-top height was at a maximum (ca. $12 \mathrm{~km}$ ) and the maximum updraft speed at altitudes above $-5^{\circ} \mathrm{C}$ was maintained at $>5 \mathrm{~m} \mathrm{~s}^{-1}$ (Figs. 2d, e, f). The third case was a multicell thunderstorm (T3) observed on 22 August 2013 (Figs. 2g, h, i) and the analysis period extended from the developing stage to the dissipating stage. The lifetime of T3 was $>2$ hours and the echo-top height began to increase at 19:20 Japan Standard Time (JST), and this was associated with an increase in the maximum updraft speed (Figs. 2g, h). The CG lightning occurred when, or after, the echo-top height was maintained in the upper troposphere (at about $15 \mathrm{~km}$ ) and when the maximum updraft speed was strong $\left(\mathrm{w}>10 \mathrm{~m} \mathrm{~s}^{-1}\right)$ above an alti-
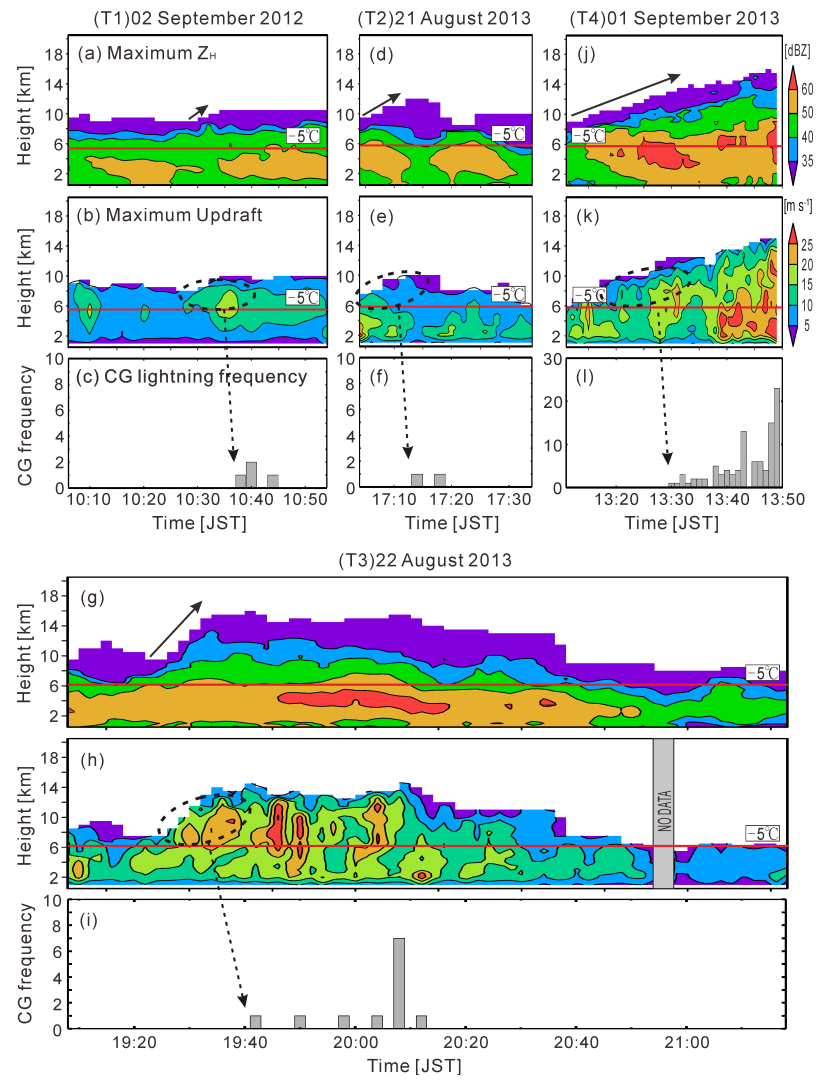

Fig. 2. Time-height cross-sections of maximum reflectivity (a, d, g, j) and maximum updraft speed ( $b, e, h, k)$, and time series of cloud-toground (CG) lightning frequency $(\mathrm{c}, \mathrm{f}, \mathrm{i}, \mathrm{l})$. The red line indicates the $-5^{\circ} \mathrm{C}$ altitude above which thunderstorm electrification takes place (Deierling and Petersen 2008). The units of CG frequency for 2 September 2012, 21 August 2013, and 22 August 2013 are number per $2 \mathrm{~min}$, whereas for 2 September 2013 it is number per $1 \mathrm{~min}$. 
tude of $-5^{\circ} \mathrm{C}$ (Figs. $2 \mathrm{~g}, \mathrm{~h}, \mathrm{i}$ ). The fourth case was a tornadic supercell thunderstorm (T4) observed on 2 September 2013 (Figs. 2j, $\mathrm{k}, \mathrm{1}$ ), and the associated tornado occurred in Saitama and Chiba prefectures after 14:00 JST (Suzuki et al. 2014; Nishihashi et al. 2015). The analysis period was from the initiation to the eve of tornado formation. The echo-top height gradually increased after the initiation of T4 and eventually reached a height $16 \mathrm{~km}$ at 13:48 JST (Fig. 2j). The CG lightning occurred when, or after, the maximum updraft speed became strong $\left(\mathrm{w}>15 \mathrm{~m} \mathrm{~s}^{-1}\right)$ above an altitude of $-5^{\circ} \mathrm{C}$ (Figs. 2k, 1). The CG lightning was first observed at 13:30 JST, and the CG lightning frequency appeared to increase in association with an increase in the maximum updraft speed in the upper troposphere and the echo-top height between 13:30 and 13:49 JST (Figs. 2k, 1). The CG lightning activity of T4 was the most active among the four thunderstorms (the three other thunderstorms exhibited low CG lightning activity; Table 1). These observations indicate a similarity among the four thunderstorms in that the CG lightning occurred once the updraft speed in the upper troposphere had first increased and then been maintained at the higher speed. The polarity of all of the CG lightning associated with the four thunderstorms was negative during the analysis periods.

\subsection{Features of the LIs for the four thunderstorms}

We investigated two relationships between CG lightning activity and LIs based on updraft strength: (1) the relationship between the CG lightning frequency and the LIs based on updraft strength, and (2) the relationship between the occurrence of CG lightning and the LIs based on updraft strength. Seven LIs based on the updraft strength above the melting level (where thunderstorm electrification takes place) were compared with CG lightning activity. These seven LIs were the mean updraft speed at all grid points with vertical velocities greater than $0 \mathrm{~m} \mathrm{~s}^{-1}\left(\mathrm{~W}_{\text {mean }}\right.$ in Table 2 ), the maximum updraft speed ( $\mathrm{W}_{\max }$ in Table 2 ), and updraft volumes with vertical velocities greater than $0,5,10,15$, and $20 \mathrm{~m} \mathrm{~s}^{-1}$ $\left(\mathrm{W}_{0}, \mathrm{~W}_{5}, \mathrm{~W}_{10}, \mathrm{~W}_{15}\right.$, and $\mathrm{W}_{20}$ in Table 2 , respectively). The threshold values of vertical velocities of Deierling and Petersen (2008), $\mathrm{W}_{0}, \mathrm{~W}_{5}, \mathrm{~W}_{10}, \mathrm{~W}_{15}$, and $\mathrm{W}_{20}$, were used in this study.

We examined the linear correlation coefficients between the CG lightning frequency and each LI derived from the updraft strength (Table 2). The analysis height of Deierling and Petersen (2008), of altitudes above $-5^{\circ} \mathrm{C}$, was used in this study. Results for the four cases combined showed that the LIs derived from the updraft volumes were well correlated with CG lightning frequency for threshold values of updraft speed of 5 and $10 \mathrm{~m} \mathrm{~s}^{-1}$ (correlation coefficient $(r)>0.7)$. For the high-CG lightning activity storm (T4), the LIs of updraft volume and mean updraft speed were well correlated with CG lightning frequency $(\mathrm{r}>0.7)$, and the LIs with high updraft speeds $\left(\mathrm{W}_{10}, \mathrm{~W}_{15}\right.$, and $\left.\mathrm{W}_{20}\right)$ were especially well correlated with CG lightning frequency $(\mathrm{r}>0.8)$.

We also investigated the relationships between the occurrence of CG lightning and the LIs based on the updraft strengths of the four thunderstorms. An analysis height of above the $-5^{\circ} \mathrm{C}$ level was also used in this analysis. These LIs were expressed in terms of the hit rate (HR), the false alarm ratio (FAR), the probability of detection (POD), and the critical success index (CSI) according to the relationships:

$$
\begin{aligned}
& \mathrm{HR}=(\mathrm{A}+\mathrm{D}) /(\mathrm{A}+\mathrm{B}+\mathrm{C}+\mathrm{D}) \\
& \mathrm{FAR}=\mathrm{B} /(\mathrm{A}+\mathrm{B}+\mathrm{C}+\mathrm{D})
\end{aligned}
$$

Table 2. Linear correlation coefficients between the CG lightning frequency and each $\mathrm{LI}$ based on the updraft strength. $\mathrm{W}_{0}, \mathrm{~W}_{5}, \mathrm{~W}_{10}, \mathrm{~W}_{15}, \mathrm{~W}_{20}, \mathrm{~W}_{\max }$, and $\mathrm{W}_{\text {mean }}$ indicate the lightning indices (LIs) of updraft volumes at vertical velocities of $>0,5,10,15$, and $20 \mathrm{~m} \mathrm{~s}^{-1}$, the maximum updraft speed, and the mean updraft speed, respectively. P-values of the results shown in Table 2 are $<0.05$.

\begin{tabular}{lccccccc}
\hline & $\mathrm{W}_{0}$ & $\mathrm{~W}_{5}$ & $\mathrm{~W}_{10}$ & $\mathrm{~W}_{15}$ & $\mathrm{~W}_{20}$ & $\mathrm{~W}_{\max }$ & $\mathrm{W}_{\text {mean }}$ \\
\hline T1, T2, T3, T4 & 0.68 & 0.77 & 0.80 & 0.65 & 0.64 & 0.39 & 0.53 \\
T4 & 0.75 & 0.78 & 0.83 & 0.82 & 0.87 & 0.50 & 0.74 \\
\hline
\end{tabular}

$\mathrm{POD}=\mathrm{A} /(\mathrm{A}+\mathrm{C})$

$\mathrm{CSI}=\mathrm{A} /(\mathrm{A}+\mathrm{B}+\mathrm{C})$, and

where the parameters $\mathrm{A}, \mathrm{B}$, and $\mathrm{C}$ denote the number of hits, false alarms, and detection misses, respectively, and where $\mathrm{D}$ is the number of non-associated events. The threshold values for each LI for the updraft strength were changed in small increments, and the HR, FAR, POD, and CSI values for each threshold value were examined. Table 3 lists the HR, FAR, POD, CSI, and threshold values for each LI when the POD was $>0.9$ and HR was at a maximum. Results for the four cases combined showed that the HR of the four LIs derived from updraft strength $\left(\mathrm{W}_{0}, \mathrm{~W}_{5}, \mathrm{~W}_{10}\right.$, and $\mathrm{W}_{\max }$ ) was $>0.7$. In the high-CG lightning activity case (T4) the LIs of the updraft volumes $\left(\mathrm{W}_{0}\right.$ and $\left.\mathrm{W}_{5}\right)$ showed the highest $\mathrm{HR}$, and those of the maximum updraft speed showed the lowest HR among the seven LIs. On the other hand, in the low-CG lightning activity cases (T1, T2, and T3) the LI of the updraft volumes at vertical velocities $>0 \mathrm{~m} \mathrm{~s}^{-1}$ showed the highest HR among the seven LIs. The threshold value of each LI that yielded the highest HR varied in each case.

To evaluate the LIs based on the updraft speed, we compared them with a LI based on reflectivity. The LI for a reflectivity of $>40 \mathrm{dBZ}$ at $-10^{\circ} \mathrm{C}$ is a representative LI for reflectivity (e.g. Gremilion and Orvile 1999), and we investigated the HR, FAR, POD, and CSI using this LI. For the four cases combined, the HR, FAR, POD, and CSI were $0.60,0.38,0.93$, and 0.32 , respectively, which was lower than the LIs derived from the updraft strength $\left(\mathrm{W}_{0}, \mathrm{~W}_{5}, \mathrm{~W}_{10}\right.$, and $\left.\mathrm{W}_{\max }\right)$.

\section{Discussion and summary}

This study examined the relationships between CG lightning activity and updraft characteristics (i.e., updraft volume, maximum updraft speed, and mean updraft speed) for four thunderstorms that displayed a variety of storm morphologies and lightning activity. Three-dimensional data for the four thunderstorms were obtained from the Kanto region, Japan, during the summer seasons of 2012 and 2013, using two X-band polarimetric radars recording at intervals of 1 or $2 \mathrm{~min}$.

For the four thunderstorms combined, the two LIs based on an updraft volume in the charging zone (above an altitude of $-5^{\circ} \mathrm{C}$ ) of $>5$ and $>10 \mathrm{~m} \mathrm{~s}^{-1}$ showed clear relationships with $\mathrm{CG}$ lightning frequency $(\mathrm{r}>0.7)$. These results are in agreement with those of Deierling and Petersen (2008), although they used total lightning data. For the high-CG lightning activity storm, the LIs with high updraft speeds $\left(\mathrm{W}_{10}, \mathrm{~W}_{15}\right.$, and $\mathrm{W}_{20}$ ) were especially well correlated with CG lightning frequency $(\mathrm{r}>0.8)$, which suggests

Table 1. Summary of the thunderstorm data. All times are in Japan Standard Time (JST). The data for vertical velocity at $20: 56$ JST on 22 August 2013 were not used for the analysis because of invalid data. Maximum area (horizontal reflectivity $\left.\left(\mathrm{Z}_{\mathrm{H}}\right)>35 \mathrm{dBZ}\right)$ at $3 \mathrm{~km}$ in height is calculated. Maximum area

\begin{tabular}{|c|c|c|c|c|c|c|c|}
\hline & Case & Storm type & $\begin{array}{c}\text { Radar volume } \\
\text { analysis period } \\
\text { (JST) }\end{array}$ & $\begin{array}{l}\text { Time interval of } \\
\text { sector volume scan } \\
\text { (min) }\end{array}$ & $\begin{array}{l}\text { Number of } \\
\text { CG lightning }\end{array}$ & $\begin{array}{l}\text { Sounding data } \\
\text { (JST) }\end{array}$ & $\begin{array}{l}\text { Maximum area } \\
\text { at } 3 \mathrm{~km} \text { in height } \\
\left(\mathrm{km}^{2}\right)\end{array}$ \\
\hline $\mathrm{T} 1$ & 02 September 2012 & Multicell & $10: 06-10: 54$ & 2 & 4 & 09 & 206 \\
\hline $\mathrm{T} 2$ & 21 August 2013 & Isolated cumulonimbus & $17: 04-17: 34$ & 2 & 2 & 21 & 67 \\
\hline $\mathrm{T} 3$ & 22 August 2013 & Multicell & $19: 08-21: 18$ & 2 & 12 & 21 & 158 \\
\hline $\mathrm{T} 4$ & 02 September 2013 & Tornadic supercell & $13: 11-13: 49$ & 1 & 98 & 09 & 199 (194) \\
\hline
\end{tabular}
$\left(\mathrm{Z}_{\mathrm{H}}>36 \mathrm{dBZ}\right)$ is shown in a parenthesis. 
Table 3. Values of the hit rate (HR), the false alarm ratio (FAR), the probability of detection (POD), the critical success index (CSI), and the threshold value (TV) of the LI for the updraft strength (see the caption to Table 2 for details of the updraft strength). The scores and threshold values were obtained when the POD value was $>0.9$ and the HR was at its highest.

\begin{tabular}{|c|c|c|c|c|c|c|c|c|c|c|c|c|c|c|c|}
\hline \multirow{2}{*}{$\begin{array}{l}\text { Various LIs of } \\
\text { updraft strength }\end{array}$} & \multicolumn{5}{|c|}{$\begin{array}{c}\mathrm{T} 1 \\
\text { 02 September } 2012 \\
\end{array}$} & \multicolumn{5}{|c|}{$\begin{array}{c}\text { T2 } \\
21 \text { August } 2013 \\
\end{array}$} & & & & & \\
\hline & HR & FAR & POD & CSI & TV & HR & FAR & POD & CSI & TV & & & & & \\
\hline $\mathrm{W}_{0}$ & 0.92 & 0.08 & 1.00 & 0.60 & $568-584$ & 0.75 & 0.25 & 1.00 & 0.33 & $68-82$ & & & & & \\
\hline $\mathrm{W}_{5}$ & 0.68 & 0.32 & 1.00 & 0.27 & $41-46$ & 0.63 & 0.38 & 1.00 & 0.25 & 4 & & & & & \\
\hline $\mathrm{W}_{10}$ & 0.72 & 0.28 & 1.00 & 0.30 & $2-3$ & & condit & on was & ot sati & & & & & & \\
\hline $\mathrm{W}_{15}$ & & condit & n was & $\begin{array}{l}\text { ot sati } \\
\mathrm{m} \mathrm{s}^{-1}\end{array}$ & fied & & & $\begin{array}{l}w>1 \\
w>2\end{array}$ & $\begin{array}{l}\mathrm{m} \mathrm{s}^{-1} \\
\mathrm{~m} \mathrm{~s}^{-1}\end{array}$ & & & & & & \\
\hline $\mathrm{W}_{\max }$ & 0.56 & 0.44 & 1.00 & 0.21 & 11 & 0.25 & 0.75 & 1.00 & 0.14 & $3-5$ & & & & & \\
\hline $\mathrm{W}_{\text {mean }}$ & 0.68 & 0.32 & 1.00 & 0.27 & 2.2 & 0.31 & 0.69 & 1.00 & 0.15 & $1.4-1.7$ & & & & & \\
\hline \multirow{2}{*}{$\begin{array}{l}\text { Various LIs of } \\
\text { updraft strength }\end{array}$} & \multicolumn{5}{|c|}{$\begin{array}{c}\text { T3 } \\
22 \text { August } 2013\end{array}$} & \multicolumn{5}{|c|}{$\begin{array}{c}\mathrm{T} 4 \\
\text { 02 September } 2013 \\
\end{array}$} & \multicolumn{5}{|c|}{ ALL } \\
\hline & HR & FAR & POD & CSI & TV & HR & FAR & POD & CSI & TV & HR & FAR & POD & CSI & TV \\
\hline $\mathrm{W}_{0}$ & 0.85 & 0.15 & 1.00 & 0.38 & $397-447$ & 0.95 & 0.05 & 1.00 & 0.46 & $585-606$ & 0.81 & 0.18 & 0.93 & 0.49 & $435-447$ \\
\hline $\mathrm{W}_{5}$ & 0.77 & 0.23 & 1.00 & 0.29 & $77-79$ & $\begin{array}{l}0.95 \\
0.95\end{array}$ & $\begin{array}{l}0.05 \\
0.03\end{array}$ & $\begin{array}{l}1.00 \\
0.94\end{array}$ & $\begin{array}{l}0.90 \\
0.89\end{array}$ & $\begin{array}{l}121-133 \\
147-154\end{array}$ & 0.80 & 0.18 & 0.90 & 0.47 & $71-73$ \\
\hline $\mathrm{W}_{10}$ & 0.71 & 0.29 & 1.00 & 0.24 & $9-11$ & 0.92 & 0.08 & 1.00 & 0.86 & $28-29$ & 0.77 & 0.21 & 0.90 & 0.43 & 8 \\
\hline $\mathrm{W}_{15}$ & 0.74 & 0.26 & 1.00 & 0.26 & 0 & 0.85 & 0.13 & 0.94 & 0.74 & 2 & \multirow{2}{*}{\multicolumn{5}{|c|}{$\begin{array}{l}\text { condition was not satisfied } \\
\text { condition was not satisfied }\end{array}$}} \\
\hline $\mathrm{W}_{20}$ & \multicolumn{5}{|c|}{ condition was not satisfied } & \multicolumn{5}{|c|}{ condition was not satisfied } & & & & & \\
\hline $\mathrm{W}_{\max }$ & 0.75 & 0.25 & 1.00 & 0.27 & 16 & 0.77 & 0.21 & 0.94 & 0.65 & 16 & 0.72 & 0.26 & 0.90 & 0.39 & 13 \\
\hline $\mathrm{W}_{\text {mean }}$ & 0.60 & 0.40 & 1.00 & 0.19 & 3 & 0.90 & 0.10 & 1.00 & 0.82 & $3.2-3.3$ & 0.54 & 0.44 & 0.93 & 0.29 & 2.4 \\
\hline & & & & & & 0.90 & 0.08 & 0.94 & 0.81 & $3.4-3.5$ & & & & & \\
\hline
\end{tabular}

that the most appropriate LI depends on the CG lightning activity level.

An LI based on updraft strength and used to estimate the occurrence of CG lightning was also investigated in this study. Results for the four thunderstorms combined showed that the four LIs derived from updraft strength, updraft volumes at vertical velocities of $>0,>5$, and $>10 \mathrm{~m} \mathrm{~s}^{-1}$ and maximum updraft speed, corresponded closely to the occurrence of CG lightning (the highest HR was $>0.7$ when POD was $>0.9$ ). These scores are better than the widely used LI score that was calculated using a reflectivity of $>40 \mathrm{dBZ}$ at $-10^{\circ} \mathrm{C}$.

Our results demonstrate the potential for updraft parameters to generate LIs that are more useful than those derived from reflectivity parameters. However, the number of cases is insufficient to validate the usefulness of updraft strength parameters for the detection and monitoring of CG lightning activity. Further analysis of data from many of the various thunderstorms will be necessary. In addition, polarimetric radar can help to detect hydrometeors in the charging zone, which means that polarimetric radar data could also be useful indices of CG lightning activity. In a future paper, we will use radar data with a high temporal and spatial resolution to examine the relationship between CG lightning activity and hydrometeors in the charging zone.

\section{Acknowledgements}

We acknowledge two anonymous reviewers and the editor (Dr. Tetsuya Takemi) for their constructive comments.

Edited by: T. Takemi

\section{Supplement}

Temporal variations in horizontal distribution of reflectivity at a height of $3 \mathrm{~km}$ are shown in Supplement 1.

\section{References}

Battan, L. J., 1975: Doppler radar observations of a hailstorm. J. Appl. Meteor., 14, 98-108.
Cressman, G. P., 1959: An operational objective analysis system. Mon. Wea. Rev., 87, 367-374.

Deierling, W., and W. A. Petersen, 2008: Total lightning activity as an indicator of updraft characteristics. J. Geophys. Res., 113, D16210, doi:10.1029/2007/JD009598.

Doviak, R. J., P. S. Ray, R. G. Strauch, and L. J. Miller, 1976: Error estimation in wind fields derived from dual-Doppler radar measurements. J. Appl. Meteor., 15, 868-878.

Kim, D.-S., M. Maki, and D.-I. Lee, 2008: Correction of X-band radar reflectivity and differential reflectivity for rain attenuation using differential phase. Atmos. Res., 90, 1-9.

Maesaka, T., M. Maki, K. Iwanami, S. Tsuchiya, K. Kieda, and A. Hoshi, 2011: Operational rainfall estimation by X-band MP radar network in MLIT, Japan. Proc. 35th Conf. on Radar Meteor., 12-18.

Nishihashi, M., K.-I. Arai, C. Fujiwara, W. Mashiko, S. Yoshida, S. Hayashi, and K. Kusunoki, 2015: Characteristics of lightning jumps associated with a tornadic supercell on 2 September 2013. SOLA, $11,18-22$

Protat, A., and I. Zawadzki, 1999: A variational method for real-time retrieval of three-dimensional wind field from multiple-Doppler bistatic radar network data. J. Atmos. Oceanic Technol., 16, 432-449.

Ray, P. S., C. L. Ziegler, W. Bumgarner, and R. J. Serafin, 1980: Single and multiple Doppler radar observations of tornadic storms. Mon. Wea. Rev., 108, 1607-1625.

Saito, M., M. Ishii, and A. Sugita, 2014: Comparison of directly measured current and JLDN data associated with lightning strokes hitting Tokyo Skytree. Paper presented at 23rd International Lightning Detection Conference, Vaisala, Arizona, USA.

Shimizu, S., and H. Uyeda, 2012: Algorithm for the identification and tracking convective cells based on constant and adaptive threshold methods using a new cell-merging and -splitting scheme. J. Meteor. Soc. Japan, 90, 869-889.

Suzuki, S.-I., Y. Shusse, S. Shimizu, T. Maesaka, N. Sakurai, and K. Iwanami, 2014: Multi-parameter radar observation of the SaitamaChiba tornadic storm on 2 September 2013. 2014 Fall Meeting of the Meteorological Society of Japan, Fukuoka, Japan, B102, (in Japanese).

Wiens, K. C., S. A. Rutledge, and S. A. Tessendolf, 2005: The 29 June 2000 supercell observed during STEPS. Part II: lightning and charge structure. J. Atmos. Soc., 62, 4151-4177.

Zipser, E. J., and K. R. Lutz, 1994: The vertical profile of radar reflectivity of convective cells: a strong indicator of storm intensity and lightning probability? Mon. Wea. Rev., 122, 1751-1759.

Manuscript received 15 September 2015, accepted 14 November 2015 SOLA: https://www.jstage.jst.go.jp/browse/sola/ 